\title{
The Use of the Electronic Diary Food (EDIFO) Application and Their Effect on the Attitude of Pregnant Mothers
}

\author{
Rita Ridayani; Dewi Mey Lestanti; Neni San Agustina Siregar \\ Politeknik Kesehatan Kemenkes Tanjungpinang, Indonesia \\ http://dx.doi.org/10.18415/ijmmu.v8i10.3085
}

\begin{abstract}
Balanced nutrition is beneficial for physical growth and development, maintaining health, replacing body tissues, and supporting reproductive health. There are several things that need to be considered during pregnancy, including nutritional needs during pregnancy which are different for each individual and one of them is influenced by health history and previous nutritional status. To help pregnant women control their nutritional needs and solve the problems above, an Electronic Diary Food (EDIFO) application will be created as an information system for balanced nutrition intake for pregnant women. A pregnant woman can access a balanced nutrition information system application anywhere and anytime. The application can be used by all pregnant women as long as the pregnant women can connect to the internet and are able to use the internet.
\end{abstract}

Keywords: Edifo; Application; Nutrient; Pregnant; Effect

\section{Introduction}

The main public health problem in developing countries including Indonesia is nutritional problems (Rukmana, 2014). The problem of nutrition is something that really needs to be considered by the government and health workers. Pregnant women are one of the populations that are very vulnerable to nutritional problems (Saragih, 2009). Nutritional problems are an indirect cause of maternal and child mortality which can still be prevented through balanced nutritional intake (Kemenkes RI, 2014).

Balanced nutrition, especially for pregnant women, indicates that the consumption of food for pregnant women must meet the needs for themselves and for the growth and development of the fetus. Pregnant women need more nutrients than non-pregnant women, but their food consumption remains diverse and balanced in quantity and proportion (Kemenkes RI, 2014).

Balanced nutrition is beneficial for physical growth and development, maintaining health, replacing body tissues, and supporting reproductive health. There are several things that need to be considered during pregnancy, including nutritional needs during pregnancy which are different for each individual and one of them is influenced by health history and previous nutritional status (Atikah, 2011). 
The need for nutrients such as carbohydrates, proteins, vitamins and minerals during pregnancy increases to be able to meet the needs associated with changes in the mother's body and fetal development (Kemenkes RI, 2010). Factors that can affect the nutritional status of pregnant women include the attitude of pregnant women (Maryam, 2016).

The attitude of a pregnant woman will affect the decision and will also affect the behavior of the pregnant woman. Pregnant women with an attitude of concern for good nutrition are likely to provide adequate nutrition for the fetus they contain (Maryam, 2016). Based on research conducted by Goni (2013) regarding the attitudes of pregnant women with nutritional status during pregnancy at the Bahu Health Center in Manado City, it was stated that there was a relationship between the attitudes of pregnant women and nutritional status during pregnancy $(\mathrm{p}=0.003<0.05)$.

Food needs are seen not only in the portion eaten but must be determined on the quality of the nutrients contained in the food consumed. In general, the cause of malnutrition in pregnant women is due to the consumption of food that does not meet the nutritional requirements (Goni, 2013).

Fulfillment of nutrients during pregnancy is said to be sufficient if you have good eating habits or attitudes. Eating habits are a term to describe food-related habits and behaviors such as the pattern of food eaten, the frequency and portion of food, beliefs and acceptance of food (such as taboos and feelings of liking or disliking food), and the method of selecting food ingredients. to be eaten (Hasanah, 2012).

The results of Narasiang's research (2016) on the description of food consumption patterns in pregnant women in the city of Manado can be concluded that referring to the Minister of Health Regulation number 75 of 2013 concerning the Nutrition Adequacy Rate in Indonesia, pregnant women in the city of Manado have a low carbohydrate eating pattern or attitude (159, 97gr/day), sufficient protein (79.15gr/day) and high in fat (124.74gr/day).

One of the communication tools that can be carried anywhere by users is a cell phone or cellphone. The development of technology is very rapid, nowadays mobile phones are not only used for voice communication, but can also be used to search for information via the internet, socialize via social media and so on. Mobile phones can also be used to run applications that are useful for building daily attitudes related to balanced nutrition for pregnant women (Rahim, 2018).

Pregnant women currently only check the state of their womb to health workers. The health of the womb actually depends on the types of food eaten by the mother, because it is from food that the nutrients needed by the fetus to grow and develop are obtained. Currently pregnant women can consume foods that must be met through a nutritionist. The infrequent attitude of pregnant women to give priority to the fulfillment of nutrition can result in an increase in infant mortality in Indonesia.

To help pregnant women control their nutritional needs and solve the problems above, an Electronic Diary Food (EDIFO) application will be created as an information system for balanced nutrition intake for pregnant women. A pregnant woman can access a balanced nutrition information system application anywhere and anytime. The application can be used by all pregnant women as long as the pregnant women can connect to the internet and are able to use the internet.

Based on data from the Tanjungpinang City Health Office in 2018, there were 4,451 pregnant women spread across 7 Tanjungpinang City Health Centers. pregnant women with Chronic Energy Deficiency (KEK) and Anemia. We can know the nutritional status of pregnant women from monitoring weight gain during pregnancy, measuring Upper Arm Circumference (LILA) and measuring Hb levels. This is thought to be a result of the lack of attitudes of pregnant women regarding balanced nutrition that can be obtained by pregnant women in their daily eating habits. 
Looking at the data and reports, the author wants to conduct research on the use of an androidbased electronic diary food (EDIFO) application and its influence on attitudes about balanced nutrition in pregnant women by using a smartphone which is one of today's technological advances and the majority of people have used these technological advances, so that it becomes the basis of researchers to conduct research on the use of an Android-based application Electronic Diary Food (EDIFO) and its effect on attitudes about balanced nutrition in pregnant women in the Tanjungpinang Health Center work area in 2019. The problem in this research is is there any effect of using electronic diary food (EDIFO) applications on increasing attitudes of pregnant women about balanced nutrition?

\section{Research Methods}

This research is a quantitative study with a quasi-experimental design (Quasi Experiment) with a one group pre-test and post-test design. This research design uses a pretest before being given treatment, so the results will be more accurate because it can compare the conditions before and after being treated, namely to assess the use of the EDIFO application and its effect on knowledge and attitudes about balanced nutrition in pregnant women.

In the early stages, pregnant women were given a pretest using a questionnaire contained in the EDIFO application and assessed the knowledge and attitudes of mothers about balanced nutrition for pregnant women. After that, pregnant women were given an intervention in the form of knowledge about balanced nutrition using the EDIFO application. The final stage is a posttest using the same questionnaire as the pretest and reassessing the knowledge and attitudes of pregnant women about balanced nutrition using the same checklist as the pretest.

The research design model is as follows:

\begin{tabular}{|lll|}
\hline $\mathrm{O}_{1}$ & $\mathrm{X}$ & $\mathrm{O}_{2}$ \\
\hline
\end{tabular}

Keterangan:

$\mathrm{O}_{1} \quad$ : Pre Test

$\mathrm{O}_{2} \quad$ : Post Test

$\mathrm{X} \quad$ : The treatment given is in the form of an application EDIFO

This research will be carried out in March - June 2019. The research site will be carried out in the Tanjungpinang City Health Center work area. And the variables and operational definitions of this research are:

The variables in this study consist of: independent variable, namely the Electronic Diary Food (EDIFO) application.

a. The dependent variable is the knowledge and attitude of pregnant women about balanced nutrition.

b. Confounding variables are age, education, occupation, and family income.

The operational definition of each variable studied is described in the operational definition table as follows: 
Table 3 Definitions of Operational Variables

\begin{tabular}{|c|c|c|c|c|c|c|}
\hline No & $\begin{array}{l}\text { Name of } \\
\text { Variable }\end{array}$ & Definition of Operational & $\begin{array}{l}\text { Measuring } \\
\text { Tool }\end{array}$ & How To Measure & Category & Scale \\
\hline \multicolumn{7}{|c|}{ Independent variable } \\
\hline 1 & $\begin{array}{l}\text { Application } \\
\text { Electronic } \\
\text { Diary Food } \\
\text { (EDIFO) }\end{array}$ & $\begin{array}{l}\text { A use of an application or } \\
\text { software for monitoring } \\
\text { balanced nutrition for } \\
\text { pregnant women on an } \\
\text { Android-based smart phone } \\
\text { that aims for pregnant } \\
\text { women to be able to monitor } \\
\text { balanced nutritional intake }\end{array}$ & & & & \\
\hline \multicolumn{7}{|c|}{ Dependent Variable } \\
\hline 2. & $\begin{array}{l}\text { Knowledge } \\
\text { of pregnant } \\
\text { women }\end{array}$ & $\begin{array}{l}\text { The results of measuring the } \\
\text { ability of respondents to } \\
\text { answer questionnaires before } \\
\text { and after being given } \\
\text { knowledge about balanced } \\
\text { nutrition }\end{array}$ & questionnaire & $\begin{array}{l}\text { Using a } \\
\text { questionnaire that } \\
\text { has been } \\
\text { integrated with } \\
\text { the application }\end{array}$ & $\begin{array}{l}\text { Good if the } \\
\text { value is } 80 \% \text {. } \\
\text { Enough if the } \\
\text { value is } 60- \\
79 \% \text {. } \\
\text { Less if the } \\
\text { value is } 59 \%\end{array}$ & Ordinal $^{*}$ \\
\hline 3. & $\begin{array}{l}\text { Attitude of } \\
\text { pregnant } \\
\text { women }\end{array}$ & $\begin{array}{l}\text { Belief or belief and } \\
\text { emotional expression of } \\
\text { pregnant women to } \\
\text { act/respond effectively to } \\
\text { balanced nutrition }\end{array}$ & questionnaire & $\begin{array}{l}\text { Using a } \\
\text { questionnaire that } \\
\text { has been } \\
\text { integrated with } \\
\text { the application }\end{array}$ & $\begin{array}{l}\text { Using the Likert } \\
\text { scale, positive } \\
\text { and negative } \\
\text { statements: } \\
\text { 1. Agree (S): } 2 \\
\text { 2. Disagree } \\
\text { (TS): } 1 \\
\text { which has been } \\
\text { integrated in the } \\
\text { application }\end{array}$ & Ordinal $^{* *}$ \\
\hline & & & & & $\begin{array}{l}\text { Attitude : } \\
\text { Well }(\geq \\
\text { median }) \\
\text { Not enough } \\
\quad(\leq \text { median }) \\
\end{array}$ & \\
\hline \multicolumn{7}{|c|}{ Confounding Variables } \\
\hline 4. & Age & $\begin{array}{l}\text { The age of pregnant women } \\
\text { when the study was carried } \\
\text { out was based on a number of } \\
\text { years }\end{array}$ & Questionnaire & 1. $<20$ years & $\begin{array}{l}\text { Using a } \\
\text { questionnaire } \\
\text { that has been } \\
\text { integrated in the } \\
\text { application }\end{array}$ & Ordinal \\
\hline 5. & Education & $\begin{array}{l}\text { The last formal education the } \\
\text { respondent has completed }\end{array}$ & Questionnaire & $\begin{array}{l}\text { 1. 220-35 years } \\
\text { old }\end{array}$ & & Ordinal \\
\hline 6. & Work & $\begin{array}{l}\text { Routine activities that get } \\
\text { rewarded by pregnant women }\end{array}$ & Questionnaire & 1. > 35 years old & $\begin{array}{l}\text { Using a } \\
\text { questionnaire } \\
\text { that has been } \\
\text { integrated in the } \\
\text { application }\end{array}$ & Nominal \\
\hline 7. & $\begin{array}{l}\text { Family } \\
\text { Income }\end{array}$ & $\begin{array}{l}\text { The amount of income that a } \\
\text { family earns in each month }\end{array}$ & Questionnaire & $\begin{array}{l}\text { I. Elementary/juni } \\
\text { or high school }\end{array}$ & & Ordinal \\
\hline
\end{tabular}

Note: For analysis purposes, it is transformed to a scale of 100 into intervals

*) Score $100=100$ (total score) / number of questions

**) Score 


\section{A. Research Population and Sample}

\section{Population}

The target population in this study were all pregnant women in the Tanjungpinang City Health Center work area based on data from January - March 2019 as many as 75 people. (Tanjungpinang City Health Center). The affordable population in this study were pregnant women in the Tanjungpinang City Health Center working area who met the inclusion and exclusion criteria with data from January - March 2019.

\section{Sample}

Sampling in this study used a probability sampling technique which is a sampling technique that provides equal opportunities for each member of the population to be a sample using simple random sampling. Samples are taken randomly, regardless of the level in the population, each element of the population has an equal and known chance of being selected as an object.

The sample in this study were pregnant women in the Tanjungpinang City Health Center working area during the study period who met the inclusion criteria and did not include the exclusion criteria and were willing to participate in the study by signing the respondent's consent form. The number of samples is determined using the Slovin formula which can represent the existing population and can reduce bias in sampling with an error rate of $10 \%$ which is very suitable for the data collection technique using simple random sampling.

Information:

$$
\mathrm{n}=\frac{\mathrm{N}}{1+\mathrm{Ne}^{2}}
$$

n: number of samples

$\mathrm{N}$ : total population

$\mathrm{e}=$ allowance for inaccuracy due to tolerable sampling error or what is known as precession $(10 \%)$.

With this formula, the number of research samples is:

$$
\begin{aligned}
& \mathrm{n}=\frac{\mathrm{N}}{1+\mathrm{Ne}^{2}} \\
& \mathrm{n}=\frac{75}{1+75(0,1)^{2}} \\
& \mathrm{n}=\frac{75}{1+75}(0,1)^{2} \\
& \mathrm{n}=43
\end{aligned}
$$

Based on the Slovin formula above, the calculation results are 42.85 . So, the number of samples obtained is 43 (42.85 rounded) from a total population of 75 with an error rate of $10 \%$.

Sampling by simple random sampling. The steps in sampling are:

a. Identify the Puskesmas used in the study, then record the number of pregnant women. 
b. After getting the number of pregnant women, the researchers recorded the names of pregnant women in the population on paper. The paper is rolled up and put in a glass/box.

c. Shake until it can match the number of samples that have been set to determine the number of pregnant women to be sampled. Research subjects are pregnant women whose rolls of paper containing names come out of a whisk will be the sample in this study.

d. Drop Out Category

1) Mothers who have given birth at the time of the research

2) Pregnant women who resigned as respondents during the study.

3) The mother whose cellphone was damaged during the research

Then the data were analyzed by univariate, bivariate and multivariate. Univariate analysis was carried out for data on the characteristics of pregnant women, namely age, education, occupation, and income. Then to find out the difference in the mean of 2 variables with a numerical and categorical scale. The statistical test was used because the data were not normally distributed, so the Independent $\mathrm{T}$ test could not be used, so the nonparametric test was used, namely the Mann Whitney Test. And the difference is considered significant if the test results $\mathrm{p}$ value $<0.005$. Furthermore, the multivariate test is carried out to see the confounding variables that can be included in the research model described in the conceptual framework. The test used is Multivariable Logistic Regression with risk factor/factor interaction test and confounding test.

\section{Result and Discussion}

\section{A. Deportment}

Attitude is a positive or negative feeling as a person's response to an object, person and environment, as a result of the knowledge and experience that has been obtained. The attitude itself has four levels, namely accepting, responding, appreciating and being responsible (Notoatmodjo, 2012b). For the realization of an attitude to become a real behavior, supporting factors or enabling conditions are needed. Factors that can influence attitudes include personal experience, the influence of other people who are considered important, cultural influences, mass media, educational institutions and religious institutions as well as emotional stress factors (Notoatmodjo, 2012; Azwar, 2011).

\section{Attitude Component}

There are three components of attitude that have been put forward, namely (Azwar, 2011):

a. Cognitive component The belief that individuals have in an opinion on issues that are developing in society.

b. Affective component The emotional aspect of a person which is the basis of an attitude and lasts the longest, and has the greatest influence in changing a person's attitude.

c. Conative component The tendency of a person to react to an event in his own way.

\section{B. Result of the Research}

In this chapter the author will describe and discuss the results of the research that has been carried out, namely the effect of using the electronic diary food (EDIFO) application on increasing the attitudes of pregnant women about balanced nutrition in the Tanjungpinang Health Center work area in 2019. The subjects in this study were pregnant women in the area. Tanjungpinang City Health Center that meets the inclusion criteria and does not meet the exclusion criteria. Subjects in this study amounted to 43 people. Each respondent was given a pre-test then given information and explanations about counseling and the 
application of electronic diary food (EDIFO) then at the next meeting a post-test was given. In the extension method, a post test was carried out at that time, while the electronic diary food (EDIFO) application method was given 1 week.

The research data obtained through questionnaires include data on respondents' characteristics, knowledge and attitudes of pregnant women about balanced nutrition. In this study, characteristic data was recorded for all respondents, including age, education, occupation and family income. Measurement of knowledge and attitudes was carried out before and after the intervention. Prior to data analysis, the data normality test was carried out on the knowledge and attitude variables. Testing the normality of the data using the Shapiro-Wilk test (sample 50) the data is said to be normally distributed if the p value> 0.05 is obtained.

\section{Characteristics of the Research}

Characteristics of research subjects were analyzed to determine the distribution or distribution and assess the equality of research subjects. The following are the results of a univariable analysis of the characteristics of research subjects consisting of age, education, occupation and family income.

Table 4.1 Frequency Distribution of Research Subject Characteristics $(n=43)$

\begin{tabular}{|c|c|c|}
\hline Subject Characteristics & $\mathbf{n}$ & $\%$ \\
\hline \multicolumn{3}{|l|}{ Age } \\
\hline$<20$ years & 1 & 2,3 \\
\hline $20-35$ years old & 37 & 86,1 \\
\hline$>35$ years old & 5 & 11,6 \\
\hline \multicolumn{3}{|l|}{ Education } \\
\hline Elementary/Junior High & 5 & 11,6 \\
\hline High School/Equivalent & 22 & 51,2 \\
\hline College & 16 & 37,2 \\
\hline \multicolumn{3}{|l|}{ Work } \\
\hline unemployment & 27 & 62,8 \\
\hline employment & 16 & 37,2 \\
\hline \multicolumn{3}{|l|}{ Income } \\
\hline Low $(<$ IDR $2,500,000)$ & 14 & 32,6 \\
\hline $\operatorname{High}(\geq \mathrm{Rp} 2,500,000)$ & 29 & 67,4 \\
\hline
\end{tabular}

Based on table 4.1, it can be seen that the characteristics of respondents from 43 pregnant women in the Tanjungpinang Health Center work area based on age who participated in this study were at most 2035 years old by $86.1 \%$ of respondents, the rest aged $>35$ years by $11.6 \%$ of respondents and aged $<20$ years by $2.3 \%$ of respondents. Characteristics of respondents based on education, at most $51.2 \%$ of respondents had high school education, while the remaining $11.6 \%$ of respondents had elementary/junior high school education and $37.2 \%$ of respondents had tertiary education. Characteristics of respondents based on the work involved the most in this study amounted to $62.8 \%$ of respondents did not work, while the remaining $37.2 \%$ of respondents worked. Furthermore, the characteristics of respondents based on family income are at most $67.4 \%$ of respondents earning UMR, while the remaining $32.6 \%$ of respondents are earning <UMR.

\section{Testing the Normality of Attitude Data Before and After Treatment}

Testing the normality of knowledge and attitude data before and after the provision of counseling and the EDIFO application was used to determine whether the data was normal or not. carried out using Shapiro-Wilk (sample 50) with the criteria if the p value $>0.05$, then the knowledge and attitude data before and after the provision of counseling and the EDIFO application were declared normal. 
Table 4.2 Normality Test of Knowledge and Attitude Data Before and After Intervention

\begin{tabular}{|c|c|c|}
\hline \multirow[t]{2}{*}{ Variable } & \multicolumn{2}{|c|}{$\begin{array}{c}\text { Normality test } \\
p \text { value }\end{array}$} \\
\hline & counseling & Android \\
\hline \multicolumn{3}{|l|}{ Deportment } \\
\hline Pre-test & 0,123 & 0,123 \\
\hline Post-test & 0,106 & 0,088 \\
\hline
\end{tabular}

Note: Shapiro-Wilk test (sample 50)

*: LG10(k-x) data transformation is carried out substantially negative skewness,

Based on table 4.2 above, the results of the normality test of knowledge and attitude data before and after the provision of counseling and EDIFO applications obtained $\mathrm{p}$ value $>0.05$, which means that knowledge and attitudes data before and after the provision of counseling and EDIFO applications were normally distributed.

2. Effect of Mother's Knowledge Before and After Intervention

Table 4.3 Mother's Knowledge Before and After Intervention

\begin{tabular}{lcccccc}
\hline \multirow{2}{*}{ Knowledge } & \multicolumn{3}{c}{ counseling } & \multicolumn{3}{c}{ Android } \\
\cline { 2 - 6 } & Median & range & $\boldsymbol{P}$ Value & Median & range & $\boldsymbol{p}$ Value \\
\hline Pre-test & 0 & 0 & & 0 & 0 & \\
Good $(\geq 80 \%)$ & 66,67 & $60-77$ & & 66,67 & $60-77$ & \\
Enough $(60-79 \%)$ & 51,67 & $43-57$ & $0,000^{*}$ & 51,67 & $43-57$ & $0,000^{* *}$ \\
Less $(\leq 59 \%)$ & & & & & \\
Post-test & 81,67 & $80-90$ & & 100 & $83-100$ & \\
Good $(\geq 80 \%)$ & 68,33 & $63-77$ & & 0 & 0 & \\
Enough $(60-79 \%)$ & 53,33 & $47-57$ & & 0 & 0 & \\
Less $(\leq 59 \%)$ &
\end{tabular}

Note: *: test results using Paired T-Test

**: test results using Wilcoxon

Based on the data obtained the effect of providing counseling and EDIFO application can increase knowledge significantly $(\mathrm{P}=0.000)$. For pre-test knowledge in the extension method and android in the sufficient category with a median value of 66.67 and a range of 60-77, while the post-test extension is in the good category with a median value of 81.67 and a range of 80-90. and the android method is in the good category with a median value of 100 and a range of 83-100.

\section{Effect of Mother's Attitude Before and After Intervention}

Table 4.4 Mother's Attitude Before and After Intervention

\begin{tabular}{lcccccc}
\hline \multirow{2}{*}{ Deportment } & \multicolumn{3}{c}{ counseling } & \multicolumn{3}{c}{ Android } \\
\cline { 2 - 6 } & Median & range & $\boldsymbol{p}$ Value & Median & Range & P Value \\
\hline Pre-test & 31 & $29-36$ & & 31 & $29-36$ & \\
Good $(\geq 29)$ & 27 & $24-28$ & $0,001^{*}$ & 27 & $24-28$ & $0,000^{*}$ \\
Less $(<29)$ & & & & 31 & $28-36$ & \\
Post-test & 31 & $28-35$ & & 27 & $24-27$ & \\
$\quad$ Good $(\geq 28)$ & 26,5 & $21-27$ & & & \\
Less $(<28)$ & &
\end{tabular}

Note: *: test results using Paired T-Test

Based on the data, it was found that the effect of providing counseling and the EDIFO application could significantly improve attitudes. The pre-test attitude in the extension method and android was in the 
good category with a median value of 31 and a range of 29-36, while the post-test extension was in the good category with a median value of 31 and a range of 28-35. and the android method is in the good category with a median value of 31 and a range of 28-36.

\section{Discussion}

According to Eka Mardiana Afrilia stated that the incidence of malnutrition that occurs in pregnant women on average with a low level of education (44\%). the relationship between mother's education and knowledge of balanced nutrition. The results of this study are in accordance with research (Budiani, 2010) which says that the level of education affects the mother's level of knowledge. Education is closely related to the way a person's attitude in perceiving something to making certain decisions for their own health problems. The higher a person's education, the better they should behave.

The results of the tests conducted on the difference in attitude improvement after the provision of counseling and the EDIFO application there were no significant differences because the $\mathrm{p}$ value $>0.05$.

\section{The Effect of EDIFO Counseling and Electronic Diary Food Applications on Increasing Pregnant Women's Attitudes about Balanced Nutrition}

In this study, the attitude variable obtained a p-value of 0.002 , meaning that the effect of providing counseling and the EDIFO application could significantly improve attitudes with the extension method decreased by $-0.01 \%$ and android increased $0.23 \%$.

The results of this study are in line with Wijayati. W 2013, there was no difference in attitude improvement regarding the implementation of post-counseling relactation between using group discussion methods and interactive lectures in the Sambi Health Center Work Area. The increase in respondents' attitudes about the implementation of relactation in the extension group using the group discussion method and interactive lectures was also influenced by the extension process itself. This is in accordance with the theory which states that counseling can increase the value of attitudes (Azwar 2007). In the extension process there is communication between participants and facilitators and vice versa as well as between extension participants. Changes in attitude are also influenced by the length of time a person remembers a message. In accordance with the theory that people may still remember the contents of the message delivered within a few hours to 5 days after the message was delivered, but forget who the source of the message is, which in the end the attitude change that occurs will not be as much as when they still remember who the source of the message is. or the communicator. So in this study the extension method experienced a decrease in the attitude value after being given an intervention.

Attitude is a reaction or response that is still closed to a stimulus or object. In a person, attitudes are formed after the process of knowing beforehand. Information from the media will carry a suggestive message that is strong enough to provide an effective basis for assessing something so that a certain attitude direction is formed. The positive attitude of the respondents is reflected in the EDIFO application, which is $0.23 \%$. The distribution picture can be interpreted that the mother's attitude is more positive. A positive attitude is manifested by an attitude of interaction and curiosity about information concerning himself about the nutritional needs of pregnant women. The results of this study are in line with the research of Javier al Fath, et al 2017 that access information about pregnancy to help pregnant women. Through current technological developments to access information can be found easily, one of which is the use of mobile phones with the Android operating system. Android users in Indonesia are 81\% of men, 19\% of women, most of whom are aged 25-34 years. 54\% of Android users are urban people, 30\% are suburban people, and $14 \%$ are rural people. Android is a new generation of mobile platform, a platform that gives developers the ability to develop as expected.

Based on Nisa Noveani's 2017 research on android-based adolescent health education applications, it is stated that the application rating is $85 \%$, which means it is very good. This shows that according to 
adolescents' perceptions, android-based adolescent reproductive health applications can add to their understanding of reproductive health, are interesting to use, easy to understand and remember, increase motivation to learn reproductive health, and are in accordance with the needs of high school youth. Increased knowledge does not always lead to behavior change, but there is a positive relationship with behavior change. Behavior is determined by three factors; enabling factor, reinforcing factor and predisposing factor. Factors that influence the process of forming attitudes are personality, intelligence, and interests. One of the functions of the application is to arouse someone's interest.

According to Notoatmodjo S, 2010, attitude is a readiness to respond that is positive or negative to an object or situation consistently. Attitude is a tendency to act from individuals in the form of closed responses to certain stimuli or objects. Attitudes indicate a suitability of reactions to stimuli that already involve a person's opinion and emotional factors. So attitude is not an action or activity, but is a tendency to take action or behavior or roles. If some of the respondents have a negative attitude, then their actions and behavior will tend to be negative, so that nutritional problems in pregnant women or themselves will occur.

\section{Conclusions and Suggestions}

\section{A. Conclusion}

Based on the results of the study, it can be concluded several things as follows:

1. There is an effect of implementing the EDIFO application in improving attitudes significantly compared to the extension method, $\mathrm{P}$ value $=0.002$.

2. There is an influence between the characteristics of the respondents which include age, education, occupation has a value of $p<0.05$ is a confounding factor that has an influence on increasing the mother's attitude, while at the attitude of $\mathrm{p}>0.05$ there is no relationship.

\section{B. Recommendation}

\section{Theoretical Suggestions}

Further research is needed to see the increase in the use of this application system not only on nutritional needs, but on the needs of pregnant women as a whole and a longer research time and increase in content in the EDIFO application.

\section{Bibliography}

Anastasia P.G.Goni, Joice M.Laoh, Damajanty H-C P Angemanan. Hubungan Pengetahuan dan Sikap Ibu hamil dengan status gizi selama kehamilan di Puskesmas Batu Kota Manado. Ejunar Kep (e-kp) vol No.1 Agustus 2013.

Bazaliel R Narasiang, Melimayulu, Sirley Kawengian Gambaran Pola Konsumsi Makanan Pada Ibu Hamil Di Kota Manado. Jurnal e-Biomedik (e Bm) Vol 4 No.2 Juli Desember 2016.

Beernatal saragih analisis kebijakan penanganan masalah gizi dan kaltim berdasarkan pengalaman berbagi. Journal gizi indonesia volume 30.1 :12-24.2009

Creswell, J.W. Pendekatan kualitatif, kuantitatif dan Mixed. Dalam Reasearch Design. Yogyakarta. 2013. 
Denis Nurah Hasanah, Febrianti, Minsar Nawanti. Kebiasaan Makan menjadi salah satu penyebab KEK pada ibu hamil di poli Kebidanan PSI Cirendeu Tangsel. Jurnal Lasprol Vol 3 N0.3 Desember 2012: 91104

Devi, M. Analisis Faktor-faktor yang Berpengaruh Terhadap Status Gizi Balita di perdesaan. Teknologi dan Kejuruan. Volume 33. No 2. 2010.

Dinas kesehatan Kota Tanjungpinang. 2017. Data Dinas Kesehatan Bidang Kesehatan Kota Tanjungpinang 2016-2017. Tanjungpinang : Dinkes Tanjungpinang.

Dinas kesehatan Provinsi Kepulauan Riau. 2017. Data Dinas Kesehatan Bidang Kesehatan Provinsi Kepri 2016-2017. Tanjungpinang : Dinkes Kepri Kuswanti, I. 2014. Askeb II Persalinan. Yogyakarta : Pustaka Pelajar.

Emzir. Metode Penelitian Kualitatif. Jakarta. Hal 79. 2010.

Gibson, R.S. Principles of Nutritional Assessment. Second Edition. 2005.

Jannah R. Pengaruh pemberian suplemen vitamin terhadap perubahan status gizi (bb/u) Balita bawah garis merah (bgm) Di wilayah kerja puskesmas kambat utara Kabupaten hulu sungai tengah (hst). 2010.

Kemenkes RI. Pedoman Gizi Seimbang (Pedoman Teknis bagi Petugas dalam Memberikan Penyuluhan Gizi Seimbang). Direktorat Jenderal Bina Gizi dan KIA KKR. Jakarta: Kemenkes RI. 2018.

Mayid TH, Herawati Dewi Marhaeni Diah. Pemberian minuman formula kacang merah, kacang tanah, dan kacang kedelai terhadap status gizi ibu hamil KEK. Journal gizi kanik indonesia . volume 14 No L-Juli 2017 (1-9).

Marhaeni. Perilaku Keluarga dalam Pemenuhan Gizi Balita di Wilayah Puskesmas Mangara Bombang Kabupaten Takalar. Jurnal Media Kebidanan Poltekkes Makasar. Nomor 2. Ed 2. 2010.

Moleong, JL. Metodologi Penelitian Kualitatif. Jakarta. 2010.

Marangoni F, Cetin I, Verduci E, Canzone G, Giovannini M, Scollo P, et al. Maternal diet and nutrient requirements in pregnancy and breastfeeding.An italian cosensus document.Nutrients.2016;8(10):1-17

Marmi. (2013). askeb pada masa antenatal. yogyakarta: pustaka belajar.

Noer Z, Kardhinata H. Kajian Perubahan Pola Konsumsi Pangan di Sumatera Utara. Agrobio. Volume I. 2009.

Peristyowati y, Siyoto S, Hasdianah. Gizi, Pemanfaatan Gizi, Diet, dan Obesitas. Yogyakarta. Hal 103-114. 2014.

Purnasari G, Briawan D, Dwiriani CM. Kepatuhan konsumsi suplemen kalsium serta hubungannya dengan tingkat kecukupan kalsium pada ibu hamil di kabupaten jember.Jurnal Kesehatan Reproduksi.2016

Prawirohardjo S. 2010. Ilmu Bedah Kebidanan. Edisi ke-1. Jakarta: PT. Bina Pustaka Sarwono Prawirohardjo.

Proverwati atikah dan siti asfuah 2011. Buku Ajar gizi kebidanan. Halaman 36-37. Yogyakarta : naha medika

Radian Rahim, Solli Aryza Lubis, Dinal Akhiar Perancangan Aplikasi Pemenuhan Kebutuhan Gizi Pada Ibu Hamil dengan Metode Copper Berbasis. Jurnal teknik informatika.volume 5 No.2 Juli 2018. 
Riyadi H, Sukandar D. Asupan gizi anak balita peserta posyandu. Jurnal Gizi dan Pangan, 4(1):42-51. 2009.

Sugiyono. Statistik Non Parametrik untuk Penelitian. Bandung. 2001.

Sastroasmoro, S. Dasar-dasar Metodelogi Penelitian Klinis, hlm 287-292. Sagung Seto. Jakarta. 2011.

Siti Maryam. 2016. Gizi dan kespro. Jakarta : salemba medika.

Siva Cardra Rukmana, Martha Irene Kartasurya Hubungan Asupan Gizi Dan Status Gizi Ibu Hamil TM III , Dengan Berat Badan Lahir Bayi Di Wilayah Kelurahan Puskesmas Seluruh Kabupaten Semarang Juornal Of Nutrision College, Volume 3, Nomor 1 Tahun 2014 Hal 129-199

Suryono DW, Wirakusumah FF, Anwar AD. The correlation beetween calcium serum and calcium urine level with the blood presure in preeclampsia. Indones J Obstet Gynecol. 2012;36(1):3-7

Sulistyowati E, Rosidi A. Peran Pendidikan dan Pekerjaan ibu dalam konsumsi sayuran anak prasekolah. Jurnal Gizi Universitas Muhammadiyah Semarang. Volume 1. 2012.

Wirawani, Aini, NQ. Kontribusi MP-ASI biscuit substitusi tepung garut, kedelai, dan ubi jalar kuning terhadap kecukupan protein, vitamin A, kalsium, dan zinc pada bayi. Journal of Nutrition College. Volume 2. 2013.

Widianarko. Seri Iptek Pangan Volume 1: Teknologi, Produk, Nutrisi \& Kemanan Pangan, Jurusan Teknologi Pangan - Unika Soegijapranata, Semarang. 2000.

\section{Copyrights}

Copyright for this article is retained by the author(s), with first publication rights granted to the journal.

This is an open-access article distributed under the terms and conditions of the Creative Commons Attribution license (http://creativecommons.org/licenses/by/4.0/). 